\title{
Dergiabant
}

Cilt/Volume: 9, Sayı/Issue: 1

(Mayıs/May 2021)

\section{Zıhâra Dair Bir Değerlendirme}

\section{An Evaluation about the Zihār}

\author{
Şükrü Şirin \\ Dr. Öğr. Üyesi, Sakarya Üniversitesi, İlahiyat Fakültesi, \\ Arap Dili ve Belagatı Anabilim Dalı \\ Asst. Prof. Dr., Sakarya University, Faculty of Theology, \\ Department of Arabic Language and Rhetoric \\ Sakarya/Turkey \\ ssirin@sakarya.edu.tr \\ orcid.org/0000-0001-8881-9261

\section{Makale Bilgisi Article Information}

Makale Türü: Araștırma Makalesi Article Type: Research Article

Geliș Tarihi: 20 Şubat 2021 Date Received: 20 February 2021

Kabul Tarihi: 16 Nisan 2021 Date Accepted: 16 April 2021

Yayın Tarihi: 30 Mayıs 2021 Date Published: 30 May 2021

Yayın Sezonu: Bahar Publication Season: Spring

https://doi.org/10.33931/abuifd.883640

İntihal/Plagiarism

Bu makale özel bir yazılımla taranmış ve intihal tespit edilmemiştir. This article has been scanned by a special software and no plagiarism detected.

\section{Atıf/Cite as}

Şirin, Şükrü. "Zıhâra Dair Bir Değerlendirme”. Dergiabant 9/1 (Mayıs 2021), 461-481. https://doi.org/10.33931/abuifd.883640

Copyright $\odot$ Published by Bolu Abant Izzet Baysal University Faculty of Theology, Bolu, 14030 Turkey. All rights reserved. https://dergipark.org.tr/tr/pub/dergiabant 


\title{
Zıhâra Dair Bir Değerlendirme
}

\begin{abstract}
Öz
İslâm dininin temel kaynakları olan Kur'ân ve sünnet nasları, toplumun temelini teşkil eden aileye ilişkin pek çok hukuki hükme yer vermiştir. Bu düzenlemeler eşlerin hak ve vazifelerini adalet ve hakkaniyet temeline dayandırmaktadır. Kur'ân'ın ailede haksızlığa yol açan Câhiliye uygulamalarına yönelik yaptı̆̆ı düzenlemelerden birisi de zıhârı yererek buna yönelik cezaî tedbirler getirmesidir. Zıhâr, kocanın karısına belirli sözleri söyleyerek gerçekleştirdiği ve hukuki sonuçları olan bir tasarruftur. İslâm hukukçuları hukuki sonuç doğuran sözleri sarih ve kinaye şeklinde ikili bir taksime tabi tutmuşlardır. Bir lafzın delaleti konusunda dinin belirlediği özel bir anlam yoksa örfü esas almışlardır. Zıhârın keyfiyetine dair naslarda belirleyici bir ifade olmadığı için bu konuda da örf esas alınmalıdır. Ancak örfteki bu anlamın, başka kelimelerle ifade edilip edilemeyeceği konusu tartışmalı olup genel kabul bu konuda kinâye lafızlara itibar edilmesi yönündedir. Bu makalede söz konusu yaklaşımın isabetli olmadığı düşüncesinden hareket edilerek zıhârda kullanılan zahr kelimesinin mecâzî anlamda kullanıldığı ve bunun yerine kullanılacak Arapça veya Türkçe bir başka kelimenin aynı manayı ifade etmeyeceği ortaya konulmaya çalışılacaktır. Câhiliye dönemindeki anlam ve fonksiyonunu yitiren zıhâr için kullanılan lafızların genişletilmesi, maslahat ve maksada uygun bir durum olmayacaktır. $\mathrm{Bu}$ nedenle zıhârdaki lafzî formun korunması ve başka ifadelerin aynı manaya gelemeyeceği kanaati daha isabetli bir bakış olarak belirmektedir.
\end{abstract}

Anahtar Kelimeler: İslâm Hukuku, Zıhâr, Zahr, Talâk, Kefaret.

\section{An Evaluation about the Zihār}

\begin{abstract}
The Qur'ān and Sunna texts, which are the main sources of Islam, included many legal provisions regarding the family that constitutes the foundation of the society. One of the juristic regulations made by the Qur'ān regarding the practices of the Jāhiliyya period which caused injustice in the family is that reproaching the zihār and imposing punitive measures on it. Zihār is a form of divorce in which the husband utters certain words to his wife and has legal consequences. Islamic jurists divided the words that have legal consequences into two types: Clear words (șarịh) and allusive words (kināya). If there is no special meaning determined by religion about the meaning that a term signifies, they have taken the custom (al-'urf) as basis. Since there is no decisive expression in the verses about the features of the zihār, the custom should be taken as a basis in this issue as well. In this article, we will try to reveal that the word zahr is used in the act of zihār as a metaphor and there is no word expressing the same meaning in Turkish nor in Arabic. Expanding the words used for zihār, which has lost its meaning and function in the period of Jāhiliyya, would not be an appropriate for interest and purpose. As a result, the idea of preserving the literal form of zihār, and the thought that the other expressions cannot have the same meaning, are appearing as more accurate perspective.
\end{abstract}

Keywords: Islamic Law, Zihār, Ẓahr, Ṭalāq, Expiation.

\section{Giriş}

İslâm'ın câhiliye dönemindeki yerleşik uygulamalar konusundaki tutumu incelendiğinde söz konusu uygulamalara yönelik üç farklı tepki ortaya koyduğu görülür. Bunlardan birincisi; İslâm öncesi var olan bir uygulamanın olduğu gibi benimsenerek devam ettirilmesi anlamına gelen ibkādır. İkincisi ise; yine var olan bir 
uygulamanın tamamen kaldırılmasını ifade eden ilgadır. Üçüncüsü de; var olan bir uygulamayı bazı değişiklikler yapmak suretiyle düzenleyip devam ettirmek şeklinde ifade edilen ıslahtır. İnşâ veya ihdâs olarak isimlendirilmesi mümkün olan dördüncü bir yöntem de, öncesinde hiç bilinmeyen ve uygulaması olmayan bir konuyu ortaya koymaktır. İlk üçüne dair çok sayıda örnek olmakla beraber sonuncusuna yönelik bir örnek vermek pek mümkün görülmemektedir. Zira uzun yıllara yayılan insanlık tarihinde, hiç uygulaması olmayan ve bilinmeyen bir hususun varlığı pek mümkün değildir. Yine de akrabalık ve evlenme engelleri konusunda öteden beri genel kurallar belirlenmiş olsa da süt emme nedeniyle oluşan akrabalık yani karâbetü'r-radâ' konusu, inşâ/ihdâs için bir örnek teşkil edebilir.

Kur'ân'ın aile içinde haksızlığa yol açan Câhiliye uygulamalarına yönelik yaptı̆̆ı düzenlemelerden birisi de zıhâr adı verilen uygulamayı yererek buna yönelik cezaî birtakım tedbirler getirmesidir. İslâm öncesi Câhiliye dönemi âdetlerinden biri olarak bilinen zıhâr, daha sonraki dönemlerde uygulama olarak çok yaygın rastlanan bir yöntem olmamıştır. İslâm'ın zıhâra bakıșı, haddizatında bu uygulamayı ortadan kaldırmaya yönelik olmakla birlikte toplumsal pratikte yer alması sebebiyle söz konusu uygulamanın doğuracağı kötü sonuçları ortadan kaldırmak ve aile içi ilişkilerin yeniden normal duruma döndürülmesi için ıslah yönünde düzenlemeler yapmaktır. Zira Câhiliye döneminde evlilik akdini bir yönüyle sonlandıran bir uygulama olan zıhâr, İslâm hukukunda aileyi sona erdiren bir uygulama olarak görülmemekle birlikte normal duruma dönüş için bir takım prosedürlerin öngörülmesi sebebiyle farklı bir yapıya bürünmüştür. Kur'ân ve sünnette zıhâr konusunda yer alan hükümler, İslâm hukukçularının aile hukukuna ilişkin meseleleri ele alırken zıhâra ilişkin hükümleri ayrıntılı bir biçimde ele almalarına önayak olmuştur. Bu kapsamda bir haksızlık olarak nitelenen zıhârın meydana geliş şekli ve hükümleri gibi konularda fıkıh literatüründe bir takım düzenlemeler yer almaktadır.

İlk dönemden günümüze kadar zıhâr bahsinin konu edildiği çalışmalarda daha çok üzerinde durulan husus zıhârın rükünleri ve zıhâr kefareti olarak görülmektedir. Gerek fıkıh gerekse tefsir literatüründe lafız açısından incelenen zıhâr, neredeyse birbirinin aynı olan ifadelerle anlatılmış olup, yazarların mensubu oldukları mezhep görüşleri çerçevesinde kalmıştır. Arap dünyasında son dönemde yapılan birkaç çalışma ise klasik kitaplardan yapılan sayfalar dolusu alıntılar içermektedir. 2003 yılında yayınlanan Tenbîhu'l-ebrâr bi'l-ahkâmi'l-hul'i ve't-talâki $v e^{\prime} z$-zıhâr isimli çalışma, ifade edilen hususun en tipik örneğidir. Musul Üniversitesi Edebiyat Fakültesi Dergisi'nde yayınlanan bir makalede ise "zhr" maddesinin sözlüklerdeki anlamı üzerinde durulmuş olup hukuki yönü ele alınmamıştır. Hasan Ali Görgülü tarafından kaleme alınan "Cahiliye Döneminde Boşanma Çeşitleri ve İslâm'ın Boşanmada Örfe İtibar Etmesi” başlıklı makalede zıhâr konusuna üç paragraf ayrılmış olup kısaca tanım ve sonucu üzerinde durulmuştur. Tespit edebildiğimiz kadarıyla konuya dair en kapsamlı çalışma, "İslâm Hukukunda Zıhâr" başlığı ile İsmail Köksal tarafından kaleme alınmış olan makaledir. Söz konusu çalışmada zıhârın 
rükünleri ve hukuki mahiyeti ele alınmış olmakla beraber zıhâr lafzı üzerinde çok fazla durulmaya gerek görülmemiştir.

Bu çalışmada zıhârın şartları, rükünleri, hükmü, sonuçları vs. hususlardan ziyade örfî bir uygulama olmasının yanı sıra zıhâr lafızlarının özel durumu ve Türkçe gibi Arapça dışında bir dilde zıhâr yapmanın mümkün olup olmadığı konusu incelenecektir. Kimlerin zıhâr yapabileceği, kimlere zıhâr yapılabileceği, kefareti gerektiren durumların neler olduğu, kefaretin mahiyeti gibi konular bu çalışmanın kapsamı dışındadır. Bu nedenle de zıhârın sözlük ve ıstılah anlamına yer verildikten sonra zıhârda kullanılan lafızlar üzerinde durulacaktır.

\section{Zıhârın Tanımı}

\subsection{Sözlük Anlamı}

Arapça asıllı zıhâr kelimesi “ ظهر " kökünden türetilmiştir. Söz konusu kelime, kökü itibarıyla oldukça geniş bir anlam yelpazesine sahip olup sözlüklerde bu kök ve bu kökten türeyen zıhâr kelimesiyle ilgili olarak onlarca mana zikredilmiş ${ }^{1}$ ve ne derece geniş bir anlam yelpazesi oluştuğu tespit edilmiştir. ${ }^{1}$ Fiil olarak kullanılması durumunda en genel anlamıyla 'ortaya çıkmak, açık olmak, belirmek, arka çımak, yükseltmek' gibi manalara gelen "ظهر” kelimesi,2 zahr şeklinde isim olarak kullanıldığında ise şu anlamlara gelmektedir:

* Her şeyin iç kısmının tersi

* Eski tencere

* Çoluk çocuk

* Kuş tüyünün kısa tarafı

* Kişinin görmediği şey

* Mecazen yük hayvanı
* İnsan bedeninin arka kısmı/sırt

* Çokça mal

* Övünmek

* Yerin yüksek kısmı

* Sirtına vurmak

* Mecazen iyilik yolu ${ }^{3}$

1 İlgili kelimenin ifade ettiği anlamların neredeyse tamamını bir arada görmek için bk. Ali Ahmed Abdu'l-âl et-Tahtâvî, Tenbîhu'l-ebrâr bi'l-ahkâmi'l-hul'i ve't-talâki ve'z-zlhâr, nşr. Muhammed Ali Beydûn (Beyrût: Dâru'l-kütübi'l-ilmiyye, 2003), 165-178.

1 'zhr' maddesinin sözlüklerde ve Kur'ân'da hangi anlamlarda olduğunu ele alan müstakil bir makale olup, kelime hakkında daha ayrıntılı bilgi için bk. Ahmet İbrahim Hızır el-Lehibî, "Mâddetü z.h.r. el-mu'cemiyye ve delâlâtühâ fi'l-Kur'âni'l-Kerîm", Mecelletü ebhâsi külliyyeti't-terbiyeti'lÍslâmiyye 2/4 (Ekim 2005), 182-188.

2 Ebü’l-Feyz Muhammed el-Murtazâ b. Muhammed b. Muhammed b. Abdirrezzâk el-Bilgrâmî elHüseynî ez-Zebîdî, Tâcü'l-arûs min cevâhiri'l-kâmûs, thk. Heyet (Kuveyt: Dâru'l-hidâye, ts.), $12 / 48$.

3 Zebîdî, Tâcü'l-arûs, 12, 479-484; Muhammed b. Ebû Bekir er-Râzî, Muhtâru's-sıhâh, thk. Yusuf eşŞeyh Muhammed (Beyrut: el-Mektebetü'l-asriyye, 1999), 197; Sa'dî Ebû Habib, el-Kamûsü'l-fikhî lügaten ve's-tılâhân (Suriye: Dâru'l-fikr, 1993), 238; Mustafa İbrahim vd., el-Mu'cemu'l-vasît (İstanbul: Çağrı Yayınları, 1989), 578. 
Aynı kökten türeyen ve konu başlığımızı oluşturan 'zıhâr' kelimesinin ise mufâale bâbından olan "ظاهر" kelimesin mastarı olduğu kabul edilmektedir.4 Dolayısıyla zâhera fiilinin anlamı da konu için önem arz etmekte olup, elbiseyi üst üste giyinmek, iki şeyi birbiriyle uyumlu yapmak ${ }^{5}$ gibi anlamlara gelmektedir. Ayrıca " ظاهر "

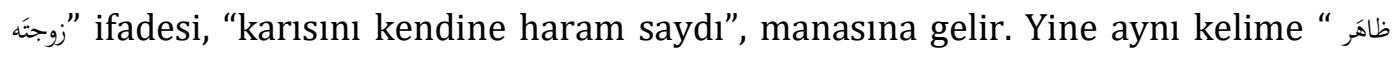
الشَّخصنَ" şeklinde kullanıldığında, “o kişiye yardım etti, arka çıktı” manalarını ifade eder. 6 Söz konusu kelimenin mastarı olan zıhâr ise sözlük anlamından ziyade ıstılah anlamıla ön plana çıkmış ve lügatlerde bu anlam üzerinde durulmuştur. Örneğin Lisânüll-Arab adlı eserde kelimenin sözlük anlamı yerine doğrudan ıstılah anlamının verildiğini ve "kişinin karısına mahremlerinden birisinin zahrı gibi olduğunu söylemesi" diyerek tarif edildiğini görüyoruz. Ayrıca bu kelimenin "min" cer harfiyle geçişlilik kazandığı da özel olarak belirtilmektedir.7 Tâcü'l-arûs isimli eserde ise zıhâr ifadesinin zahr kelimesinden alındığı ve mecazî anlam olarak kocanın eşine zıhâr yapmasını ifade ettiği belirtilir. ${ }^{8}$ Zıhâr kelimesinin arkası güçlü olan, aşırı derecede muhtaçlığı ifade etmek üzere mecazen beli bükülen, sırt ağrısı, sırt çantası gibi anlamlara geldiği, fikıh terimi olarak da "kişinin karısını, kendisine mahrem olan birisine benzetmesi" anlamında kullanıldığı söylenmektedir. ${ }^{9}$

Ertât b. Süheyye'ye (öl. 85/705) ait olduğu söylenen bir beyitte "min veledi'zzahr" şeklinde kullanılmış olup anlam olarak da, "bizden olmayan" veya "kendilerine dönüp bakmayan" ya da "akrabalarıyla ilişkiyi kesen", şeklinde yorumlanmıștır.10 Fıkıh kitaplarının vakıfla ilgili bölümlerinde de oldukça sık rastlanan bu ifade evlâd-ı zuhûr olarak terimleşmiş olup, kişinin kendi erkek ve kız evlatlarıyla oğullarının erkek ve kız evlatları anlamında kullanılmaktadır. ${ }^{11}$

Görüldüğü gibi zahr kelimesi son derece farklı ve bir o kadar da mecazî anlamlar ifade etmekte olsa da zıhâr kelimesi aynı durumda değildir. Zira zıhâr kelimesinin yaygın ıstılah anlamı, sözlük anlamının önüne geçmiş görünmektedir. Bu ise konunun hangi bağlamda ele alınacağına dair bir çerveve çizmektedir.

\footnotetext{
4 Ahmed Muhtar Abdülhamid Ömer, Mu'cemü'l-lügati'l-Arabiyyeti'l-muâsıra (Beyrût: Alemü'lkütüb, 2008), 2/1444.

5 Ebü's-Seâdât Mecdüddîn el-Mübârek b. Esîrüddîn Muhammed b. Muhammed eş-Şeybânî elCezerî İbnü'l-Esîr, Câmi'u'l-usûl fî ehâdîsi'r-Rasûl, thk. Abdülkadir el-Arnavut vd. (Dımaşk: Mektebetü'l-halvânî, 1972), 8/251; Sa'dî Ebû Habib, el-Kâmûsü'l-fikhî, 238; Mustafa İbrahim, elMu'cemu'l-vasît, 2/578.

6 Ahmed Muhtar, Mu'cemü'l-lügati'l-Arabiyyeti'l-muâsıra, 2/1442.

7 İbn Manzûr Ebü'l-Fazl Cemâlüddîn Muhammed b. Mükerrem b. Alî b. Ahmed el-Ensârî erRüveyfiî, Lisânü'l-Arab (Beyrût: Dâru sâdır, 1414/1994), 4/528.

8 Zebîdî, Tâcü'l-arûs, 12/491.

9 Mustafa İbrahim, el-Mu'cemu'l-vasît, 2/578; Ahmed Muhtar, Mu'cemü'l-lügati'l-Arabiyyeti'lmuâsıra, 2/1444.

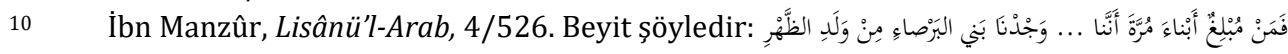

11 Mehmet Erdoğan, Fıkıh ve Hukuk Terimleri Sözlüğü (İstanbul: Ensar, 2013), 129.
} 


\subsection{Istılah Anlamı}

Zıhâr kavramının İslâm sonrası yüklendiği manaya geçmeden önce, Câhiliye Araplarında nasıl bir mana taşıdığı ve hangi amaca matuf olduğu hususunun açıklanması faydalı olacaktır. Zira söz konusu kavram ve uygulamada sonradan ne tür değişikliklerin olduğunun tespiti ancak öncesinin bilinmesiyle mümkündür.

\subsection{1. İslâm Öncesi Arap Toplumunda Zıhâr}

Câhiliye dönemi olarak isimlendirilen İslâm öncesi Arap toplumunda, çok yaygın olmasa da bir tür boşama şekli olarak bilinen zıhâr, boşamadan farklı olarak kadına yönelik ağır bir ceza ve yaptırım aracı gibi kullanılmaktaydı. Zıhâr esnasında zikredilen zahr kelimesinin cinsel beraberlikten istiare olarak kullanılmasının yanı sıra kocanın, kendisinden razı olmadığı eşine sırtını dönmesinden ve onu bırakmasından dolayı da böyle bir isimlendirmenin yapıldığı söylenmektedir. ${ }^{12}$ Dolayısıyla zıhârda boşamaktan farklı olarak kişinin cinsel açıdan eșiyle birlikte olmayı bırakması, yani evli bir kadının cinsel anlamda kocasız kalması durumu vardı. Zıhâr yapan kocanın kadın üzerindeki yetkisi devam ettiği için, bir başka deyişle tam bir boşama gerçekleşmediği için kadın bir başkasıyla evlenememekte, fakat kocasından da istifade edememekteydi. Erkek ise başka bir kadınla evlenmek veya mevcut diğer eşlerinden istifade etmek konusunda ayrıcalıklı bir konumda bulunmaktaydı. Bu durum ise kadın açısından boşanmaktan daha ağır bir sonuç ortaya çıkarıyordu. ${ }^{13}$ Cevâd Ali, (öl. 1315/1897) Câhiliye döneminde zıhârın ağır bir boşama şekli olduğunu ifade etse de kadının bir başkasıyla evlenmesine mani bir durum olduğundan bahsetmemiştir. ${ }^{14}$

M. Tâhir b. Âşûr, (öl. 1392/1973) zıhâr uygulamasının Arap toplumunda fazlaca bilinmediğine delil olarak Mekke, Tihâme, Necid gibi bölgelerde bu uygulamaya rastlanmadığını, bunun sadece Medine ve civarındaki yerlerde bilinen bir uygulama olduğunu ve muhtemelen Yahudilerden öğrenildiğini belirtmektedir. Ayrıca zıhârın Mekkî surelerde zikredilmeyişini de bu görüşüne delil olarak sunmaktadır. ${ }^{15}$ Zıhârla ilgili nasları değerlendirirken de ifade edileceği gibi ilk zıhâr olayıyla karşılaşıldığı zamandaki Rasulullah'ın (s.a.v.) tavrı da bu uygulamanın çok yaygın olmadığını göstermektedir.

Kaynaklarda yer alan zıhârın tanımına dair ifadelerin ortak noktası ise, bir

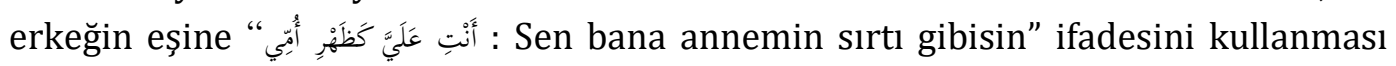
sonucunda karısını kendisine ebedî olarak haram kılmasıdır. Önemine binaen tekrar edecek olursak; zıhâr uygulaması ile cezalandırılan bir kadın ve o kadına yönelik özel bir ilgisi yoksa bunun sonuçlarından hiç etkilenmeyen bir erkek söz konusu

\footnotetext{
12 Ahmet Yaman, "Zıhâr", Türkiye Diyanet Vakfı İslâm Ansiklopedisi (İstanbul: TDV Yayınları, 2013), $44 / 387$.

13 Şemsüddîn Muhammed b. Ahmed el-Hatîb eş-Şirbînî el-Kâhirî, Muğni'l-muhtâc ilâ ma 'rifeti me‘ânî elfâzi'l-Minhâc (Beyrût: Dâru'l-kütübi'l-ilmiyye, 1994), 5/29.

14 Cevâd Ali, el-Mufassal fî târîhi'l-Arabi kable'l-İslâm (Beyrût: Dâru's-sâkî, 2001), 10/223.

15 Tâhir b. Âșûr, et-Tahrîr ve't-tenvîr (Tunus: ed-Dâru't-Tûnusiyye li'n-neșr, 1984), 28/11.
} 
olmaktadır. İslâm hukukunda yer alan zıhâra dair düzenleme ile kadının mağduriyeti bir ölçüde giderilmiş olmaktadır.

\subsection{2. İslâm Hukukuna Göre Zıhâr}

İslâm öncesi dönemde bilinen zıhâr tanımı ile İslâm sonrası tanımı arasında lafız olarak çok büyük bir fark olmasa da fonksiyon olarak oldukça farlılık ortaya çıkmıştır. Islah veya ilgâ olarak değerlendirebileceğimiz ${ }^{16}$ bu farklılıklara geçmeden önce zıhâr kelimesinin ıstılah anlamına genel olarak yer vermekte fayda mülahaza edilmektedir. Zıhâr, günümüze ait çalışmalardan biri olan Fıkıh ve Hukuk Terimleri Sözlüğü isimli eserde şöyle tanımlanmaktadır: "Kocanın, karısını nesep, süt emme veya sihriyyet sebebiyle ebediyen kendisine evlenmesi haram olan bir kadının kendisince bakılması caiz olmayan arkası, karnı, uyluğu gibi bir uzvuna benzetmesidir..."17 Konuya dair bir başka tarif ise şu şekildedir: "Zıhâr terimi kocanın, kendisine haram kılmak maksadıyla karısını veya karısının baş, yüz, sırt gibi bütünü ifade eden bir bölümünü evlenmesi dinen yasak olan yakını (mahrem) bir kadına benzetmesi demektir."18

Klasik dönem fıkıh eserlerinde yer alan zıhâr tanımları birbiriyle çok yakın olup aradaki farklar tanımdan ziyade unsurlarının veya rükünlerinin tanıma dahil edilmesiyle ortaya çıkmaktadır. Mesela Hanefîlerden bazıları, "kişinin nikâhlı eşini kendisine ebedî haram olan bir kadına benzetmesidir", diyerek benzetilen kadının ebedî haram olma özelliğini öncelemişken, ${ }^{19}$ bazıları buna benzetilen uzuvla ilgili hususları da eklemişlerdir. Hanbelîler ise "zıhâr, kocanın karısını veya onun bir uzvunu kendisine bir sürelik de olsa haram olan birine veya onun bir uzvuna benzetmesidir"20 şeklinde bir tarif yapmışlardır. Buna mukabil Şâfiîler, daha yalın bir ifade kullanarak uzuvlardan bahsetmeksizin sadece kişinin eşini, kendisine helal olmayan bir kadına benzetmesi üzerinde durmuştur. ${ }^{21}$ Mâlikî fakihler de Hanefîler gibi kapsamlı bir tarif ortaya koyarak, kendisine benzetilen kadının ebedî haram olanlardan biri olmasına vurgu yapmışlardır.22 Bir kimsenin cariyesine zıhâr yapıp yapamayacağı ise ayrı bakış açılarından değerlendirilmiş ve ihtilafa konu olmuștur. ${ }^{23}$

Fıkıh kitaplarında yer alan bu tariflerin neredeyse aynısının pek çok tefsir ve hadis kitabında ve hatta lügatlerde de yer aldığı görülmektedir. Söz konusu tanımların

16 Zihâr uygulamasına dair getirilen yeni hükmün nesih sadedinden olduğu görüşü için bk. Râzî, Ebû Abdillâh (Ebü'l-Fazl) Fahrüddîn Muhammed b. Ömer b. Hüseyn er-Râzî et-Taberistânî, Mefâtîhu'lğayb (Beyrût: Dâru ihyâi't-türâsi'l-Arabî, 1420/1999), 29/477.

17 Erdoğan, Fıkıh ve Hukuk Terimleri Sözlüğ̈̈, 620.

18 Yaman, "Zıhâr", 44/387.

19 Ebü'l-Berekât Hâfızüddîn Abdullah b. Ahmed b. Mahmûd en-Nesefî, Kenzü'd-dekâik, thk. Said Bektaș (Beyrût: Dâru'l-beşâiri'l-İslâmiyye, 2011), 297.

20 Zeynüddîn Merî̀ b. Yûsuf b. Ebî Bekr b. Ahmed b. Ebî Bekr el-Kermî, Gâyetü’l-müntehâ (Kuveyt: Müessesetü gırâs, 2007), 2/338.

21 Şirbînî, Muğni'l-muhtâc, 5/29.

22 Şemsüddîn Ebû Abdillâh Muhammed b. Ahmed b. Arafe ed-Desûkî, Hâşsiyetü'd-Desûkîale'ş-Şerhi'lkebîr (Beyrût: Dâru'l-fikr, ts.), 2/439.

23 Ebû Muhammed Muvaffakuddîn Abdullāh b. Ahmed b. Muhammed b. Kudâme el-Cemmâîlî elMakdisî, el-Muğnî (Kahire: Mektebetü'l-Kahire, 1968), 8/12-13. 
mukayesesi yapıldığında ise temel ortak noktanın bir kişinin nikâhı altındaki karısını, kendisine haram olan bir kadına benzetmesi olarak görülmektedir. Kendisine benzetilen kadında, benzetilen uzuvda, kullanılan ifadelerde vs. aranan şartlar ise konunun teferruatı sadedinde farklı başlıklar altında zikredilmiştir. Ancak bu çalışmada ele alınmak istenen asıl konu zıhâr lafızları ile ilgili olduğu için bahsi geçen ayrıntılara yer verilmeyecektir.

\subsubsection{Sonuçları Bakımından Farklılıklar}

Câhiliye döneminde zıhârın sonucu olarak bir çeşit boșama gerçekleștiğini ve fakat bu boşamanın kadını tam anlamıyla serbest bırakan ve başka biriyle evlenmesine imkân tanıyan bir boşama olmadığını ifade etmiştik. Zıhâr sonrası yapılması gerekenlere ilişkin hükümleri düzenleyen ayetlerin inmesinden sonra bu uygulama İslâm hukuku çerçevesinde yeni bir boyut kazanmıştır. Artık zıhâr bir boşama değildir ve kefaret gerektiren ağır bir günahtır. Bu sayede zıhârın faili olan erkek cezalandırılmış ve mağdur taraf konumundaki kadının hakları muhafaza edilmiştir. Zıhârın Câhiliye döneminde icra ettiği anlam ve fonksiyon tamamen yok sayılmış ama ısrar edenlere de bir yaptırım ve ceza getirilmiştir. ${ }^{24}$

\section{Zıhâra Dair Naslar}

Zıhâr kelimesi Kur'ân-ı Kerîm'de bu hâliyle geçmemekte olup fiil formatında ve burada kastedilen anlamıly üç yerde geçmektedir. Ahzâb suresinde ظظهرون şeklinde kullanıldığı ayetin sevk sebebi zıhâr olmadığı için, bu ayetin tefsirini yapanlar zıhâr konusuna fazla değinmemişlerdir. Ayetin ilgili bölümünün meali şu şekildedir: “...zıhâr yaptı̆̆ınız eșlerinizi de analarınızın yerinde tutmadı..."25 Zıhâr konusunun ayrıntılı olarak ele alındığı ve hükmünün ortaya konulduğu ayetler ise Mücâdele suresinin 2 ve 3. ayetleridir. İlgili ayetlerin nüzul sebebi de dikkate alındığında bu ayetlerin Ahzâb suresindeki ayetten önce indiği anlaşılmaktadır. Her iki ayette de يظاهرون ş̧eklinde geçen kelimenin okunuşunda pek çok kıraat farklılıkları olsa da26 anlam açısından büyük ölçüde ittifak edildiği görülmektedir. Mücâdele suresindeki bu iki ayet ve mealleri şu şekildedir:

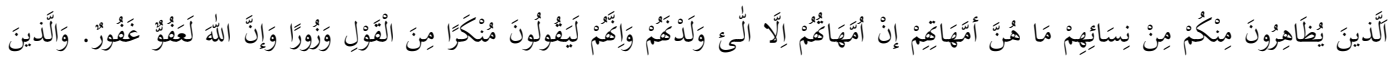

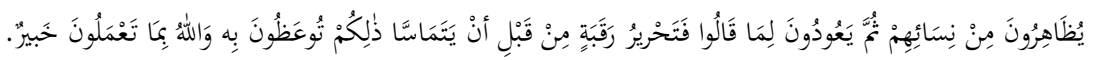

"İçinizden zıhâr yapanların kadınları, onların anaları değildir. Onların anaları ancak kendilerini doğuran kadınlardır. Şüphesiz onlar çirkin bir laf ve yalan söylüyorlar. Kuşkusuz Allah, affedicidir, bağışlayıcıdır. Kadınlardan zıhâr ile

24 İslâm hukukundaki zıhâra yönelik düzenlemeler ve cezalar için bk. İsmail Köksal, "İslâm Hukuku'nda Zıhâr", Dini Araștırmalar 3/7 (Mayıs-Ağustos 2000), 260-268.

25 Kur'ân-ı Kerîm ve Açıklamalı Meâli, çev. Hayrettin Karaman vd. (Ankara: Türkiye Diyanet Vakfı Yayınları, 2018), el-Ahzâb 33/4.

26 İlgili kelimelerdeki kıraat farklılıkları için bk. Ebû Ca'fer Muhammed b. Cerîr b. Yezîd el-Âmülî etTaberî el-Bağdâdî, Câmi'u'l-beyân fî te'vîli'l-Kur'ân, thk. Ahmed Muhammed Şâkir (Beyrût: Müessesetü'r-risâle, 2000), 23/228; Ahmed b. Musa b. Abbas et-Temimî Ebû Bekr b. Mücahid elBağdâdî, es-Seb'atü fi'l-kırâât, thk. Şevki Dayf (Mısır: Dâru'l-meârif, 1400/1980), 628. 
ayrılmak isteyip de sonra söylediklerinden dönenlerin karılarıla temas etmeden önce bir köleyi hürriyetine kavuşturmaları gerekir. Size öğütlenen budur. Allah, yaptıklarınızdan haberi olandır."27

Zıhârla ilgili olarak nazil olan bu ayetlerde zıhârın tarifi, unsurları vs. gibi bir şey yer almadığı gibi, Câhiliye âdeti olan bu uygulamanın artık kabul edilemez bir yalan ifade olduğu ve fakat bu konuda ısrar edip zıhâr yapanların ise yine de kefareti yerine getirmesi gerektiği belirtilmektedir. Artık zıhâr, Câhiliye döneminde kabul edilen sonuçları doğuran bir uygulama olmaktan çıkmış, ceza gerektiren yalan bir söz olarak kabul edilmiştir. Kefaret olarak belirlenen cezayı gerektiren eylemin zıhâr yapmak mı yoksa yaptığı zıhârdan dönerek tekrar karısıyla birlikte olmak mı olduğu tartışmalı olsa da ${ }^{28}$ çoğunluğun kabulü zıhâr ve sonrasında hanımına dönmek ${ }^{29}$ şeklinde ikisi birden olduğu yönündedir. Bu nedenle fikıh mezhepleri tarafından genel bir biçimde kabul edildiği üzere zıhâr yapan kişi karısına tekrar dönmezse kefaret cezası ile yükümlü olmaz. Bir başka deyişle Allah tarafından haram kılınan zıhâr sözlerini sarf eden kişinin bu yaptığı günah olsa da bu sözler, kefaret yerine getirilinceye kadar karı-koca ilişkisinin haramlığı dışında bir sonuç doğurmaz. Zira zıhâr sonrasında boşamak ya da geri dönüp kefaret ödemek dışında bir ihtimal yoktur.

Hadis literatüründe yer alan zıhâra dair rivayetleri, vürut zamanına göre ikiye ayırmak mümkündür. Birinci grupta zıhâr ayetlerinin inmesi ve zıhâra dair hükmün belirlenmesi öncesine ait rivayetler, ikinci grupta da hükmün belirlenmesinden sonra varit olan rivayetler yer alır.

İslâm'da ilk zıhâr yapan kişinin Evs b. Sâmit olduğunu söyleyen rivayetler ${ }^{30}$ dikkate alındığında, Mücâdele suresinin sebeb-i nüzûlü olarak da kabul edilen bu olayın, vahiy sonrası vuku bulan ilk zıhâr olayı olduğu söylenebilir. Söz konusu olayda özetle; amca kızıyla evli olan Evs, bazı gerekçelerden dolayı zıhâr yapmış ve hanımı Havle bu durumdan rahatsız olduğu için konuyu Rasulullah'a (s.a.v.) arz etmiştir. Söz konusu rivayet kaynaklarda farklı lafızlarla zikredilmiş olmakla beraber, Rasulullah'ın (s.a.v.) "Sen ona haram oldun” demesi üzerine Havle'nin israrla "Ey Allah'ın Rasulü! Talak kelimesini söylemedi” demesi ve durumunu iyice anlatarak

27 el-Mücâdele 58/2-3.

28 Mücâhid ve Sevrî̀nin, kefareti gerektiren şeyin zıhâr olduğu ve kefaret için başka bir şart aranmadığı yönündeki görüşü için bk. Ebü'l-Velîd el-Bâcî, el-Müntekâ şerhu'l-Muvatta' (Mısır: Matbaatü's-saade, 1332/1914), 4/49; Ebü’l-Hasen Alî b. Muhammed b. Habîb el-Basrî el-Mâverdî, el-Hâvi'l-kebîr, thk. Ali Muhammed Muavviz-Adil Ahmed Abdülmevcûd (Beyrût: Dâru'l-kütübi'lilmiyye, 1999), 4/127. Ayette geçen dönmek ifadesiyle neyin kastedildiğine dair ileri sürülen farklı görüşleri bir arada görmek için bk. Ebû Bekir İbnü’l-Arabî Muhammed b. Abdillâh b. Muhammed el-Meâfirî, Ahkâmu'l-Kur'ân (Beyrût: Dâru'l-kütübi'l-ilmiyye, 2003), 4/192; İsmail Köksal, “İslâm Hukuku'nda Zihar", 261.

30 Ebû Hilâl el-Hasen b. Abdillâh b. Sehl el-Askerî, el-Evâil (Tanta: Dâru'l-beşîr, 1408/1988), 255; Mâverdî, el-Hâvi'l-kebîr, 10/411; Taberî, Câmi ‘u'l-beyân, 23/221; İbnü'l-Hümâm, Kemâlüddîn Muhammed b. Abdilvâhid b. Abdilhamîd es-Sivâsî el-İskenderî, Fethu'l-kadîr (Beyrût: Dâru'l-fikr, ts.), $5 / 220$. 
farklı bir hüküm istemesi pek çok kaynakta zikredilmektedir. ${ }^{31} \mathrm{Bu}$ rivayette dikkat çeken husus Havle'nin, eşinin kullandığı lafızlara dair bir yorum ve değerlendirme yaparak zıhârın talaktan farklı olduğuna vurgu yapması ve evvel emirde Rasulullah (s.a.v.) bunu kabul etmese de konuya dair ayetlerin nüzulü sonrasında Havle'nin düşüncesinin isabetli olduğudur. Rivayetlerin bir kısmında her ne kadar Evs'in hangi ifadeleri kullandığı yer almasa da zıhâr bilinen bir uygulama olduğundan diğer rivayetlerin de yardımıyla ne söylediği tahmin edilebilir.

Evs hadisesi ve Mücâdele suresinin inmesinden sonra olduğu düşünülen zıhâr olaylarına ilişkin rivayetlerden biri Seleme b. Sahr ile ilgilidir. Hatta bazıları Seleme olayının İslâm'da ilk zıhâr olduğunu ve ilgili ayetlerin nüzul sebebinin de bu olay olduğunu kabul etmişlerdir..$^{32}$ Ancak rivayette belirtildiğine göre, karısına zıhâr yapan Seleme önce arkadaşlarından durumu Rasulullah'a (s.a.v.) haber vermelerini ister fakat onlar kabul etmeyince kendisi gidip olayı anlatır, akabinde de Rasulullah (s.a.v.) zıhâr kefareti olarak yapması gerekenleri söyler. ${ }^{33}$ Durum böyle olduğuna göre kefaret olarak yapacağı şeylerin doğrudan zikredilmesi, bu olayın daha sonra olduğunu göstermektedir. Ancak bu rivayette de dikkat çeken husus, Seleme'nin karısına "zıhâr yaptım" demesi olup, bu manaya gelecek başka bir ifade kullanmamasıdır. ${ }^{34}$

Tirmizî'nin (öl. 279/892) Sünen'inde yer alan bir rivayette zıhâr yapan kişinin ismi zikredilmeksizin bir kimsenin Rasulullah'a (s.a.v.) gelerek karısına zıhâr yaptığı ve fakat kefaret ödemeden önce karısıyla beraber olduğunu haber verdiği yer almaktadır. ${ }^{35} \mathrm{Bu}$ rivayette de anlatımın, "karıma zıhâr yaptım" şeklinde geçmekte olduğunu belirtmek gerekmektedir.

Zıhâra ilişkin yukarıdaki rivayetlerin hiçbirinde zıhâr yaptığı söylenen sahabîlerin bu tasarrufu hangi sözlü ifadelerle gerçekleştirdikleri yönünde açık bir ibare yer almamaktadır. Tam da bu noktada ahkâm ayetleri konusunda müstakil bir eser yazan Ebu Bekir İbnü'l-Arabî’ye (öl. 543/1148) nispet edilen konuya ilişkin bir

Ebü'l-Kâsım Mahmûd b. Ömer b. Muhammed el-Hârizmî ez-Zemahșerî, el-Keșşâf 'an hakâ'ikı gavâmizi't-tenzîl ve 'uyûni'l-ekâvîl fî vücûhi't-te’vîl (Beyrût: Dâru'l-kütübi'l-ilmiyye, 1407/1987), 4/485; Râzî, Mefâtîhu'l-ğayb, 29/477; Nesefî, Tefsîru'n-Nesefî, thk. Yusuf Ali Bedevî (Beyrût: Dâru'l-kelimi't-tayyib, 1998), 3/444.

32 Hüccetü'l-İslâm Ebû Hâmid Muhammed b. Muhammed b. Muhammed b. Ahmed el-Gazzâlî etTûsî, el-Mustasfâ, thk. Muhammed Abdüsselam Abdü'ş-Șâfî (Beyrût: Dâru'l-kutubi'l-ilmiyye, 1993), 236; Molla Fenârî, Şemseddin Muhammed b. Hamza, Fusûlü'l-bedâyi 'fî usûli'ş̧-şerâi c, thk. Muhammed Hüseyin Muhammed Hasan İsmail (Beyrût: Dâru'l-kütübi'l-ilmiyye, 2006), 2/78.

33 Ebû Bekir Abdullah b. Muhammed b. Ebî Şeybe İbrâhîm el-Absî el-Kûfî, Müsned, thk. Adil b. Yusuf el-Azazî -Ahmed b. Ferid el-Mezidî (Riyad: Dâru'l-vatan, 1997), 2/136; Ebû Abdillâh Ahmed b. Muhammed b. Hanbel eş-Şeybânî el-Mervezî, el-Müsned, thk. Şuayb Arnavut-Adil Mürşid vd. (Beyrût: Müessetü'r-risale, 2001), 26/346; Ebû Abdillâh Muhammed b. Alî b. Muhammed eșŞevkânî es-San'ânî el-Yemenî, Neylü'l-evtâr, thk. İsamüddin es-Sabâbetî (Mısır: Dâru'l-hadîs, 1993), 6/307.

34 Ebû Zeyd Ömer b. Şebbe en-Nümeyrî el-Basrî, Târîhu'l-Medîne, thk. Fehim Muhammed Şeltût (Cidde: 1399/1979), 2/396.

35 Ebû Îsâ Muhammed b. Îsâ b. Sevre (Yezîd) et-Tirmizî, el-Câmi'u'l-kebîr, thk. Beşşâr Avvâd Marûf (Beyrût: Dâru'l-garbi'l-İslâmî, 1998), 2/494; Şevkânî, Neylü'l-evtâr, 6/309. 
sözün ne anlamda söylenmiş olabileceği üzerinde bir nebze durmanın gerekli olduğunu düşünüyoruz.

Zıhârla ilgili rivayetler konusunda bazı kaynaklarda Ebû Bekir İbnü'l-Arabî'ye yönelik bir eleştiri yer almaktadır. Buna İbnü'l-Arabî'nin 'zıhâr konusunda sahih bir hadis yoktur' dediği ifade edilmekte ve bu ifadesiyle aşırıya kaçtığı söylenmektedir. "36 Ancak İbnü'l-Arabî'nin Ahkâmu'l-Kur'ân adlı eserinde yukarıda zikri geçen hadislere yer vermesi ve sahih olmadıklarına dair herhangi bir söz söylememesi oldukça dikkat çekicidir. Meseleyi tetkik ettiğimizde İbnü'l-Arabî'nin böyle bir sözüne ulaşamadık; ancak neden böyle bir söyleme gidilmiş olabileceğine dair üç ihtimal tespit edebildik.

Birincisi; İbnü'l-Arabî el-Avâsım mine'l-kavâsım isimli eserinde zlhâr konusunu anlatırken 'garip bir konu' başlığı ile Dâvûd ez-Zâhirî'nin, (öl. 270/884) "zıhâr kefareti için kişinin ikinci defa zıhâr yapmış olması gerekir, ayetteki “ ثم يعودون لما قالوا ifadesi bu anlama gelir", iddiasına cevap olarak onun metodunu kullanmış ve ağır ifadeler sarf etmiştir. İbnü'l-Arabî sonrasında şunları söylemiştir: “ Ey Dâvûd; Allah'ın bildirdiği zıhârın nasıl olduğunu söyle bakalım bana! Bu kalpten geçirmek midir yoksa dil ile söylemek midir? Bana bu konuya dair sahih veya zayıf bir hadis getir. Asla böyle bir hadis getiremezsin..."37 Belki de burada ifade edilen maksat farklı anlaşılarak zıhâr konusunda sahih hadis yoktur şeklinde tevil edilmiş olabilir.

İkincisi; İbnü'l-Arabî bir önceki konunun devamında tam olarak şöyle bir ifadeye yer vermektedir:

$$
\text { " ويجب أن تعلموا أن البخاري ومسلما لم يدخلا في الظهار حرفا واحدا من الحديث. “ }
$$

"Şunu da bilmelisiniz ki Buhârî de Müslim de (sahihlerine) zıhâr hakkında hadisten tek bir harf dahi koymamışlardır." Bu ifadeden hareketle İbnü'l-Arabi'ye atfen söylenen sözün şu şekilde olması güçlü bir ihtimal gibi görünüyor. ليس في الظهار : Sahîhaynda zıhârla ilgili bir hadis yoktur.

Üçüncüsü; İbnü'l-Arabî Ahkâmu'l-Kur'ân adlı eserinde Muhammed b. Kāsım'ın kendisine naklettiği bir olaya yer vermektedir. Uzun uzun anlatılan bu olay Fustat'da Ebu'l-Fadl el-Cevherî'nin ders halkasında geçmektedir. Cevherî sohbet esnasında 'Peygamber hem boşadı hem zıhâr yaptı hem de îlâ yaptı' deyince Muhammed b. Kâsım konuşma bittikten sonra onu takip ederek Rasulullah'ın (s.a.v.) zıhâr yapmadığını ve yapmasının da doğru olmadığını ifade eder. Cevherî de hatasını kabul

36 Ebû Zekeriyyâ Yahyâ b. Șeref b. Mürî en-Nevevî, el-Mecmû'şerhu'l-Mühezzeb (Beyrût: Dârul'l-fikr, ts.), 17/365; Ebü't-Tayyib Muhammed Șemsü'l-Hak b. Emîr Alî ed-Diyânüvî el-Azîmâbâdî, Avnü'lma'bûd (Beyrût: Dâru'l-kütübi'l-ilmiyye, 1415/1995), 6/219; Ebü'l-Ulâ Muhammed Abdurrahmân b. Abdirrahîm el-Mübârekpûrî, Tuhfetü'l-ahvezî (Beyrût: Dâru'l-kütübi'l-ilmiyye, ts.), 4/319; Ebû Hafs Sirâcüddîn Ömer b. Alî b. Ahmed el-Ensârî el-Mısrî, el-Bedrü'l-münîr fî tahrîci ehâdîsi'ş-Şerhi'l-kebîr, thk. Mustafa Ebu'l-Gayt-Abdullah b. Süleyman-Yasir b. Kemal (Riyad: Dâru'l-hicra, 2004), 8/159.

37 İbnü'l-Arabî, el-Avâsım mine'l-kavâsım, thk. Ammâr Tâlibî (Mısır: Mektebetü dâri't-türâs, ts.), 271272. 
ederek sözünden vazgeçer. Zayıf bir ihtimal olsa da bu olayın anlatılması sırasında

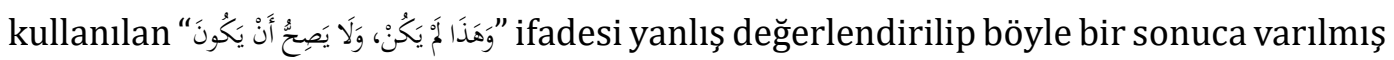
olabilir. 38

Sonuç itibariyle naslarda zıhârın nasıl yapıldığına dair bir ifadenin geçmediği görülmekte ${ }^{39}$ ve bu konuda belirleyici olanın örf olduğu anlaşılmaktadır. Dolayısıyla örfte zıhârın nasıllığı son derece belirleyici bir ölçüdür.

\section{Zıhâr İfadesinin Tahlili}

Naslarda keyfiyeti belirtilmemiş olan zıhârın ne tür bir ifade ile gerçekleştiği ittifakla kabul edilmiş olmakla beraber ifadede yer alan kavramların mahiyeti hakkında ve bunların yerine bir başka kelimenin ikame edilip edilemeyeceğine dair çok farklı yaklaşımlar bulunmaktadır. Neredeyse bütün klasik eserlerin üzerinde ittifak ettiği zıhâr uygulaması şu sözlerle gerçekleşmektedir: Bir kişinin karısına " أنتِ :عليّ كظهر أمّي : Sen bana annemin sırtı gibisin", demesidir.

Bu çalışmanın konu edindiği asıl mesele de burada yer almaktadır. Zira zıhâr ifade etmek için kullanılan bu kalıpta aynı zamanda zıhârın rükünleri de yer almaktadır. Söz konusu ifadede dört kelime üzerinde durulmuş olup bu kelimelerden her hangi birinin varlığı ya da yokluğunun hüküm üzerindeki tesiri fukaha tarafından ele alınmıştır. Bu dört kelime; “أنبِّ" zamiri ile karşılığını bulan kadın, bağlaç olarak

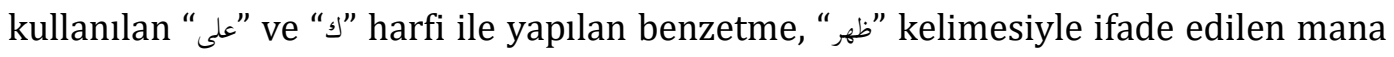
ve "م" olarak gelen anne anlamındaki kelimedir.

Zıhâr yapılması esnasında bu dört kelimenin bir arada kullanılması durumunda, başkaca bir şart veya istisnâ söz konusu değilse zıhârın gerçekleşeceğine dair müçtehitlerin ittifakı vardır. ${ }^{40}$ Ancak bu dört kelimeden her hangi birinin kullanılmaması veya yerine başka bir kelimenin kullanılması durumunda ise birtakım görüş ayrılıkları vardır. Bu kelimelerden zahr dışında olanlar hakkındaki ihtilaflara kısaca değinilecek, asıl incelenmek istenen zahr kelimesindeki ihtilaflara ise daha geniş yer verilecektir.

Birincisi; “" zamirinin yerine karısını ifade edecek bir başka kelimenin kullanılması hükmü değiştirmemektedir. Mesela “زوجت : eşim” dese ya da eşini işaret ederek $b u$, şu, o gibi bir kelime kullansa veya kendisiyle eşini kastettiği açık olarak

\footnotetext{
38 Bu konuda şimdilik ulaşabildiğimiz sonuç böyle olsa da konunun daha fazla tetkik edilmesi ve en doğru sonuca ulaşılması gerektiği de ayrıca ifade edilmelidir.

39 Bazı rivayetlerde zıhâr için kullanılan cümleye de yer verilmiș olsa da bu rivayetler kesinlik arz etmemektedir. Zıhâr esnasında nasıl bir söz sarf edildiğine dair bir rivayet için bk. İbnü’l-Arabî, Ahkâmu'l-Kur'ân, 4/190.

40 Ebû Bekr Ahmed b. Alî er-Râzî el-Cessâs, Ahkâmu'l-Kur'ân, thk. Abdüsselam Muhammed Ali Şahin (Beyrût: Dâru'l-kütübi'l-ilmiyye, 1994), 5/303; Ebû Abdillâh Muhammed b. İdrîs b. Abbâs eş-Şâfiî, el-Ümm (Beyrût: Dâru'l-marife, 1990), 5/295; İbnü'l-Arabî, Ahkâmu'l-Kur'ân, 4/191.
} 
anlaşılan bir başka kelime kullansa sonuç aynı olacaktır. ${ }^{41}$ Fakat bu kısımda kadının tamamını ifade eden söz konusu kelimeler yerine bir parçasının, mesela bir uzvunun zikredilmesi hâlinde, ileride geleceği üzere ihtilaflar vardır.

İkincisi; terkibin de ikinci unsuru olan "على" ve "s" edatları yerine, yine bu manayı verecek bir başka bağlaç kullanılması veya hiç bağlaç kullanılmaması da durumu değiştirmemekte, her iki durumda da zıhâr gerçekleşmiş kabul edilmektedir. ${ }^{42}$

Üçüncüsü; zıhâr terkibinde sonda yer alsa da kısa geçileceği için burada yer verilecek olan "أم" kelimesi yerine anne anlamına gelecek bir başka kelime kullanılması durumunda yine zıhâr gerçekleșmiş olur. Ancak anne yerine bir başka mahrem kadın zikredilmesi durumunda zikri geçen kadının ebedî mahrem olanlardan birisi olmasıyla geçici mahremlerden birisi olması arasında ayırım yapanlar olmuştur. Bu konuda genel kabul, kendisine benzetilenin kadın cinsinden ve mahrem birisi olması ise de erkeklere, mahremi olmayan kadınlara ve hatta hayvanlara benzetilmesi durumunda da zıhâr olur diyenler mevcuttur. ${ }^{43}$ Zâhirîler ve Zeydîler gibi, ${ }^{44}$ anne dışında birisine benzetilmesi durumunda zıhâr olmayacağını söyleyenler, ayetin zâhirine bağlı olarak bu görüşe gitmişlerdir.

Dördüncüsü; hiç şüphesiz zıhâr terkibinin en önemli parçası zahr kelimesidir. Zira zıhâr tabiri de bu kelimeden türetilmiştir. İlgili kelimenin sözlüklerde yer alan anlamı ve ıstılah anlamı daha önce zikredilmiști. Genel kabul, zahr kelimesi yerine, bakılması haram olan başka bir uzvun zikredilmesiyle de zıhâr olacağı yönündedir. Ancak konunun önemine binaen yeni bir başlık altında müstakil olarak incelenmesi daha faydalı olacaktır.

\section{Zahr Lafzının Özel Durumu}

Zebîdî (öl. 1205/1791) Tâcü'l-arûs isimli eserinde, Câhiliye âdeti olarak kabul edilen zıhâr kelimesinin, dindeki terim anlamının mecazî anlam olduğunu açıkça ifade etmekte, akabinde de Câhiliye döneminde Arapların bu kelimeyle eşlerini boşadıklarını beyan ile nas olarak zıhâr kalıbını bütün unsurlarıyla birlikte zikretmektedir. Ayrıca özellikle zahr kelimesinin kullanıldığını, batn, fahz, ferc gibi kelimelerin tercih edilmediğini ve bunun gerekçesinin de zahr kelimesinin anlam olarak haramlık ifade etmede diğerlerinden daha evla olduğunu söylemektedir. Zira zahr, binme mahalli olarak kabul edilmiş, kadın da bir anlamda merkûbe mahiyetinde tasvir edilmiştir. Nihayetinde bu ifadeyi kullanan birisi zımnen eşine, "ilişsi amacıyla

41 İbn Rüșd Ebü’l-Velîd Muhammed b. Ahmed b. Ahmed el-Kurtubî el-Endelüsî, el-Mukaddimâtü'lmümehhedât, thk. Muhammed Hacci (Beyrût: Dâru'l-garbi'l-İslâmî, 1988), 1/599; İbn Rüşd, elBeyân ve't-tahsîl, thk. Muhammed Hacci (Beyrût: Dâru'l-garbi'l-İslâmî, 1988), 5/198; Ebü'l-Fazl Müslim b. Ali ed-Dımașkî el-Mâlikî, el-Furûku'l-fikhiyye, thk. Muhammed Ebü'l-Ecfân - Hamza Ebû Fâris (Libya: Dâru'l-hikme, 2007), 121; Ebû Bekir Alâüddîn Muhammed b. Ahmed b. Ebî Ahmed es-Semerkandî, Tuhfetü'l-fukahâ (Beyrût: Dâru'l-kütübi'l-ilmiyye, 1994), 2/204.

Râzî, Mefâtîhu'l-ğayb, 29/479.

İbn Kudâme, el-Muğnî, 8/6.

Yaman, "Zıhâr", 44/388. 
senin üzerinde olmam annemin üzerinde olmak gibi haram olsun", demiş olmaktadır.45 Söz konusu kelimenin mecâz anlamının alınması nedeniyle, başka kelimelerin onun yerine konulmasının bir sorun teşkil edeceği açıktır.

Zıhâr kelimesinin bedenin bir uzvu olan sırt manasındaki zahr kökünden alınmadığını, aksine bu kelimenin uluv kökünden alınarak üstünde olmak ve aşmak manalarına geldiğini aktaran Râzî, (öl. 606/1210) gerekçe olarak da bir uzuv olan sirt'ın, böyle bir konumda faydalanma ve lezzet almada diğer uzuvlardan daha öncelikli olmadığını ifade etmektedir. Bu görüşün delili olarak da Kehf suresinin 97. ayetinde geçen "يظهرو" kelimesinin anlamını göstermektedir.46 Dolayısıyla zahr yerine kullanılacak diğer uzuv isimlerinde aynı mananın bulunmaması, ifade edilen asıl maksadı yansıtmayacaklarını göstermektedir.

Zıhârı mecaz olarak kabul etmeyen âlimler ise zıhâr için kullanılan lafızları sarih ve kinâye lafızlar olmak üzere ikiye ayırmışlardır. Yukarıda belirtilen șekliyle bütün unsurlarını kapsayacak bir şekilde zıhâr ifadesinin kullanılması durumunda zıhârın gerçekleșeceği ittifakla kabul edilmiş ancak kinâye olarak bu unsurların ve özellikle zahr kelimesinin yerine bir başka kelimenin kullanılmasının nasıl bir sonuç doğuracağı hakkında ihtilaf etmişlerdir. Sonuç olarak da sözü sarf edenin niyetine bakılacağını belirtmişlerdir. ${ }^{47}$

İslâm hukukunda sarih ve kinâye ayrımı oldukça yaygın ve kabul gören bir olgudur. Mesela nikâh, talak, ıtk, hibe, icâre, alım satım, vasiyet vs. gibi konularda kinâye lafızlar da sarih lafızlar gibi sonuç doğurmaktadır. Zira gerek bu uygulamalardaki maksat ve maslahatın açıkça biliniyor olması, gerekse halk arasında pek çok lafzın aynı manada kullanılmasının bir teamül olması böyle bir kabulü anlaşılır ve makul göstermektedir. Ancak zahr kelimesinin özel durumu ve kullanımı dikkate alındığında ve bu kelimenin ne anlamda kullanıldığında bir ihtilaf olduğu düşünüldüğünde kinâye lafız uygulaması biraz sorunlu olacaktır. Bununla beraber, bildiğimiz kadarıyla zahr yerine farklı bir kelime kullanılarak zıhâr yapıldığına dair bir rivayet bulunmamaktadır. Câhiliye döneminin bir örfü olan uygulamada kullanılan bu kelimeyi, bir maksada matuf olarak söylendiği kabulüyle aynı maksadı içeren başka kelimelerle karşılamak, kıyasla ulaşılan bir neticedir. Hâlbuki Kur'ân, ne zahr kelimesine ne de anne kelimesine değinmiş, sadece o dönemde insanlar arasında bilinen zıhâr kavramını dikkate almakla yetinmiştir.48

Hanefî fakihlerinden Kâsânî (öl. 587/1191) zıhâr konusunu ele alırken konuyla ilgili bilinmesi gerekenleri sıralayarak zıhârın rüknüne değinmektedir. Bunun ise zıhâra delalet eden lafız olduğunu vurgulayarak bu konuda asıl olanın

\footnotetext{
45 Zebîdî, Tâcü'l-arûs, 12/491.

46 Râzî, Mefâtîhu'l-ğayb, 29/478.

47 İbn Rüşd, Ebü'l-Velîd Muhammed b. Ahmed b. Muhammed el-Kurtubî, Bidâyetü'l-müctehid (Kahire: Dâru'l-hadîs, 2004), 3/123; 4 cilt; Ebû Abdillâh Şemsüddîn Muhammed b. Muhammed b. Abdirrahmân el-Hattâb er-Ruaynî, Mevâhibü'l-celîl fî Şerhi Muhtasarı Halil (Beyrût: Dâru'l-fikr, 1992), 4/115. 6 cilt. 3 . Basım 
kişinin karısına أنت عليّ كظهر أمّي demesi olduğunu belirttikten sonra aynı ifadede zahr yerine batn, fahz veya ferc kelimelerinin kullanılmasının da asla ilhak edileceğini belirtir. Gerekçe olarak da zıhârın manasının helal olanın harama benzetilmesi olduğunu söylemektedir. ${ }^{49}$ Ancak zıhârın burada ifade edildiği gibi bir anlama nasıl geldiği ve bu anlamın nereden alındığı belirtilmemiştir. Burada şu soru karşımıza çıkacaktır: Şayet helalin harama benzetilmesini sağlayan ifade zıhâr ise bunun yerine kullanılan kelimelerin aynı anlama geldiğini de gösteren lügavî veya örfî bir karinenin olması gerekmez mi? Hanefîlere göre, zahr kelimesi zikredilmeksizin kişi karısına 'sen benim için annem gibisin’ demiş olsa sözü söyleyen kişinin niyetine bakılır; şayet her hangi bir şeye niyet etmemişse söylediği söz herhangi bir sonuç doğurmaz. ${ }^{50}$

Aile hukukuna dair bu denli önemli konularda lafzın sarih yani açık manasının ne derece önemli olduğunu göstermesi açısından İmam Şâfiî̀nin şu değerlendirmesi manidardır: “Bir kişi karısına 'sen annemin zahrı gibi boşsun' demiş olsa ve bununla zıhâr yapmayı istese, talak sözünün sarih delaleti nedeniyle zıhâr değil boşama gerçekleşmiş olur." ${ }^{11} \mathrm{Bu}$ da gösteriyor ki İmam Şâfiî̀ye göre talak kelimesinin sarahati zahr kelimesinden daha önceliklidir.

Zahr kelimesi bedendeki bir uzuv olan sırt manasında düşünüldüğünde, zıhâr esnasında bu kelimenin yerine zikredilen diğer uzuvların mahiyeti konusunda İmam Şâfiî̀nin iki farklı görüşü olup bunlardan ilkine göre saygınlık manası taşımayan ayak, el, karın gibi uzuvların zikredilmesiyle zıhârın gerçekleşmeyeceğidir. Zaten göz, ruh gibi saygınlık manası taşıyan kelimeler kullanıldığında niyetine bağlı olarak zıhârın gerçekleşmeyeceği konusunda tek görüşü vardır.52 Şâfiî̀nin bu ayırımı da oldukça dikkat çekici görünmektedir.

Hanefî fakih Cessâs, (öl. 370/981) zıhâr ifadesinin ne olduğunu açıkça zikrettikten sonra bu ifadede geçen zahr kelimesinin yerine zikredilecek diğer azaları "bakılması haram olan azalar ve bakılması haram olmayan azalar" olarak sınıflandırmıştır. Onun belirttiğine göre bakılması haram olmayan bir aza zikredilirse zıhâr olmaz, haram olan bir aza zikredilirse zıhâr olur. ${ }^{53}$ Bu ifadeden anlaşıldığına göre Hanefîler, bakılmasının helal olup olmamasını ölçü olarak alırken ${ }^{54}$ Şâfîler istimtâ‘ yani zevk alıp faydalanma ölçüsünden hareket etmişlerdir. Bu, kıyasla ulaşılan bir hükmün illetinin ne olduğuna dair bir farklılıktır. Demek oluyor ki hüküm doğrudan nasla değil kıyasla belirlenmiştir.

Serahsî, (öl. 483/1090) Hanefî mezhebindeki genel kabulü zikrettikten sonra

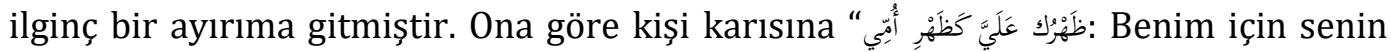

\footnotetext{
49 Alâüddîn Ebû Bekr b. Mes'ûd b. Ahmed el-Kâsânî, Bedâ’i'u's-sanâ'i' fî tertîbi'ş-şerẩi' (Beyrût: Dâru'l-kütübi'l-ilmiyye, 1986), 3/229.

50 Kâsânî, Bedâ' $i^{c}$, 3/229; Ebü'l-Hüseyn Ahmed b. Ebî Bekr Muhammed b. Ahmed el-Kudûrî, elMuhtasar, thk. Kâmil Muhammed Uveyda (Beyrût: Dâru'l-kütübi'l-ilmiyye, 1997), 165.

Sâfiî, el-Ümm, 5/296.

Râzî, Mefâtîhu'l-ğayb, 29/479.

Cessâs, Ahkâmu'l-Kur'ân, 3/566.

İbnü'l-Hümâm, Fethu'l-kadîr, 4/250.
} 
zahrın annemin zahrı gibi" dese, bu sözüyle zıhâr yapmış sayılmaz. Zira zahr kelimesi bedenin tamamı için kullanılmaz. ${ }^{55}$ Buradan anlaşıldığına göre zahr kelimesi kullanılmış olsa bile kişi eşinin tamamını ifade eden bir kelime kullanmadığı için bu söz zıhâr olarak değerlendirilmez. Ancak bedenin bir parçasının zikredilmesi bütünün hükmündedir, gerekçesiyle buna itiraz edenler olmuştur. ${ }^{56}$

Râzî, zahr kelimesi yerine, bakılması haram olsa bile sair azaların zikredilmesiyle zıhâr olmayacağı görüşünü daha isabetli bulmuş, bunun gerekçesini de gayet net bir şekilde zikretmiştir. Ona göre; kişiye karısı ile ilişkinin helal olması ve bu kişinin zimmetinin kefaret yükümlülüğü barındırmaması kesin bilinen bir durumdur ve kesin olarak bilinenin olduğu hal üzere kalması asıldır. Kişinin demesi halinde bu aslın terkedilmesini gerektiren açılk mana, bunun yerine kullanılan diğer ifadelerde bulunmamaktadır. Böyle olmasının sebebi ise Câhiliye döneminde kullanılagelen ve bilinen zıhâr ifadesinin tam olarak yukarıda söylendiği şekliyle olmasıdır ki haramlığı işaret eden lafız tam da bu olup diğerleri bu manayı taşımamaktadır. ${ }^{57}$

Zıhârda kendisine benzetilen kadın olan anne yerine mahremlerden bir başka kadın zikredilirse zıhâr gerçekleşmez diyen Râzî, burada yapılan kıyası, kıyâs maa'lfârık yani bir birbirine benzemeyenler arasında yapılmış bir kıyas olarak değerlendirmektedir. Bu konuda son derece önemli olduğunu düşündüğümüz bir tespiti de; kişinin أنت عليّ كبطن أختي sözünde olduğu gibi hem zahr hem de anne lafzı yer almamışsa bu ifade ile zıhâr olmayacağıdır. ${ }^{58}$

\section{Arapça Dışında Bir Dille Zıłâr Yapmak (Türkçe Örneği)}

Zahr kelimesinin ifade ettiği mana ve özel durumu dikkate alındığında bu kelimenin Arapça dışında bir kelime ile tam olarak karşılanması pek mümkün görülmemektedir. Mesela Türkçe açısından ele alındığında; أنتِ عليّ كظهر أمّي kullanımı, zahr kelimesinin Türkçe karşllıklarından birkaç tanesi ile çevrilmiş olsa şunlara benzer ifadeler görülecektir:

- Sen benim için annemin sırtı gibisin.

- Sen benim için annemin arkası gibisin.

- Sen benim için annemin eski tenceresi gibisin.

- Sen benim için annemin çoluk çocuğu gibisin.

- Sen benim için annemin sirt çantası gibisin.

- Sen benim için annemin yükü gibisin.

- Sen benim için annemin kamburu gibisin.

55 Ebû Bekr Şemsü'l-eimme Muhammed b. Ebî Sehl Ahmed es-Serahsî, el-Mebsût (Beyrût: Dâru'lmarife, 1993), 6/228.

56 Abdülganî b. Tâlib b. Hammâde el-Meydânî el-Guneymî ed-Dımaşkî, el-Lübâb fî şerhi'l-Kitâb, thk. Muhammed Muhyiddin Abdülhamid (Beyrût: el-Mektebetü'l-ilmiyye, ts.), 3/68.

57 Râzî, Mefâtîhu'l-ğayb, 29/479.

58 Râzî, Mefâtîhu'l-ğayb, 29/479. 
Benzerlerinin daha fazla sıralanabileceği bu ifadelerden sadece birincisinin zıhâr olduğunu, diğerlerinin ise bu anlama gelmediğini söylemek bir tercih olacaktır. Ancak böyle bir tercihi gerektirecek açlk bir karine yoktur. Yine de en uygun ve manaya münasip olan sırt şeklinde tercüme edilmesidir, dense bile bu kelimenin bedenin bir parçası olan zahr anlamında kullanılmadığını söyleyenlerin kabulüne ters düşecektir.

Türkçede zıhâr olgusunu tam olarak ifade edecek bir kelimenin bulunmaması nedeniyle bu kavram tercüme edilmeksizin olduğu gibi kullanılmıştır. Ayrıca Türk toplumunda böyle bir âdet ve kullanım bilinmemekte olup Osmanlıca yazılan fıkıh eserlerinde de söz konusu ifade tercüme edilmemiş, olduğu gibi kullanılmıştır. Mesela Behcetü'l-fetâvâ isimli eserde "زيد زوجه سى هنده سن بنم أوزريمه أنامك ظهرى كبى سن: Zeyd, zevcesi Hind'e; sen benim üzerime anamın zahrı gibisin" şeklinde ifade edilmiştir. Aynı yerde bahsi geçen diğer iki zıhâr fetvasında ise el ve ferc kelimeleri ile yapılan kullanımların zıhâr olmayacağı söylenmektedir.59

\section{Sonuç}

Zıhâr uygulaması Câhiliye adetlerinden olup İslâm böyle bir uygulamayı tasvip etmemiştir. Önceden bir tür boşama olarak kabul edilen bu ifade, Allah Teâlâ'nın beyanı ile cezayı gerektiren yalan bir söz olarak değerlendirilmiş ve kendisine ceza nitelikli bir takım hukuki sonuçlar bağlanmıştır. Câhiliye döneminde dahi yaygın olmayan bu uygulamaya İslâm sonrası dönemde de neredeyse yok denecek kadar az rastlanmıştır. Güncel meselelere dair internet üzerinden fetvalar yayınlayan dijital platformlardaki soru ve cevaplara bakıldığında tam olarak zıhârı yansıtmayacak bazı ifadelerle ilgili soruların geldiği dikkate alınırsa Arap dünyasında da aktüel değeri olmayan, unutulmaya yüz tutmuş bir uygulama görünümü vermektedir. Bu çalışmanın neticesinde elde edilen sonuçlar şu şekilde sıralanabilir.

Zıhâr ifadesi tam da Câhiliye döneminde kullanıldığı gibi veya hiç değilse zahr ifadesini uygun şekilde barındıran sözlerle yapılırsa bu söz, fakihlerin sarih zıhâr lafzı diye tarif ettikleri kapsamda olup bununla zıhâr gerçekleşmiş olur ve hukuki sonuçlarını doğurur.

Zahr kelimesinin mecâz manasının esas alındığı düşünüldügünde başka kelimelerin onun yerine aynı anlamı ifade ettiğini söylemek bir içtihat ve yorumdur ki bu içtihadı isabetli saymak bir tercih olup aksi de mümkündür.

Câhiliye döneminde icra ettiği fonksiyonu yitiren zıhârın, İslâm'a göre kefaret dışında hukuki bir sonucu kalmamıştır. Dolayısıyla dil alışkanlığı olarak ilk dönemde yapılanlar hariç tutulursa bu uygulamanın pratikte vukuu son derece zor görünmektedir. 59 Yenișehirli, Şeyhülislam Ebu'l-Fazl Abdullah Efendi, Behcetül-fetâvâ, der. Mehmed Fıkhi el-Aynî
(İstanbul: Matbaa-i Âmire, 1266), 103-104. 
Bazı lafızların kinâye olarak sarih lafız yerine kaim olması maksat ve maslahata matuf olup, zıhâr uygulamasında kinâye lafızlara itibar etmek söz konusu maksat ve maslahatla uyumlu görülmemektedir.

Herhangi bir lafız hakkında din tarafından özel bir anlam tayininde bulunulmamışsa söz konusu lafzın anlamını belirlemede örf dikkate alınır. Zıhâr konusunda ise örfte kullanılan bir başka ifade yer almamaktadır. Konuyla ilgili hadislerde sarih zıhâr ifasi zikredilmiş, ayetlerde ise eskiden beri bilinegelen uygulamaya atıf yapmakla yetinilmiştir.

Mücâdele suresinde zihâr konusunu düzenleyen ayetlerin nüzul sebebi, Havle bnt. Sa'lebe'nin ısrarı ve zıhârla boşamayı farklı görmesidir. Aynı ısrar ve itiraz erkek tarafından, zahr ifadesi kullanılmadan yapılan ve kinâye oldukları kabul edilen sözlere de yapılamaz mı?

Hakkında ihtilaf olunan konularda ihtiyatlı davranmak ilkesel olarak güzel bir davranış olsa da zıhâr konusundaki ihtilaf, ihtiyat sınırlarının ötesine geçmiş görünmektedir.

Arapça ifade tarzında dahi ihtilaf olan bir kavramın, başka dillerde tam da o manaya gelecek şekilde karşılığının olması pek mümkün değildir. Hal böyle olunca başka dilde zıhâr yapmak da mümkün olmayabilir.

Sözlü ifadelerde niyetin dikkate alınması kabul edilen bir durum olmakla birlikte zıhârın haram olduğunu bilen bir Müslümanın kullandığı sözlerle zıhâra niyet ettiğini söylemek uzak bir ihtimaldir. Zira aklı başında bir kimsenin hukuken boşama sonucu doğurmayan, sadece söyleyene kefaret yükümlülüğü getiren ve günah kabul edilen bir fiili yapması beklenmez, aksi halde kendine zarar vermiş olur. 


\section{Kaynakça}

Ahmed b. Hanbel, Ebû Abdillâh Ahmed b. Muhammed b. Hanbel eş-Şeybânî el-Mervezî. elMüsned. 45 Cilt. thk. Şuayb Arnavut-Adil Mürşid vd.. Beyrût: Müessetü'r-risale, 2001.

Ahmed Muhtar, Abdülhamid Ömer. Mu'cemü'l-lügati'l-Arabiyyeti'l-muâsıra. 4 Cilt. Beyrût: Alemü'l-kütüb, 2008.

Ali, Cevâd. el-Mufassal fí târîhi'l-Arabi kable'l-İslâm. 20 Cilt. Beyrût: Dâru's-sâkî, 4. Basım,2001.

Askerî, Ebû Hilâl el-Hasen b. Abdillâh b. Sehl el-Askerî. el-Evâil. Tanta: Dâru'l-beşîr, 1408/1988.

Azîmâbâdî, Ebü't-Tayyib Muhammed Şemsü'l-Hak b. Emîr Alî ed-Diyânüvî el-Azîmâbâdî. Avnü'l-ma'bûd. 14 Cilt. Beyrût: Dâru'l-kütübi'l-ilmiyye, 4. Basım, 1415/1995.

Bâcî, Ebü'l-Velîd el-Bâcî. el-Müntekâ şerhu'l-Muvatta'. 7 Cilt. Mısır: Matbaatü's-saade, $1332 / 1914$.

Bağdâdî, Ahmed b. Musa b. Abbas et-Temimî Ebû Bekr b. Mücahid el-Bağdâdî. es-Seb'atü fi'lkırâât. thk. Şevki Dayf. Mısır: Dâru'l-meârif,1. Basım, 1400/1980.

Cessâs, Ebû Bekr Ahmed b. Alî er-Râzî el-Cessâs. Ahkâmu'l-Kur'ân. 3 Cilt. thk. Abdüsselam Muhammed Ali Şahin. Beyrût: Dâru'l-kütübi'l-ilmiyye, 1994.

Desûkî, Şemsüddîn Ebû Abdillâh Muhammed b. Ahmed b. Arafe ed-Desûkî. Hâşiyetü'd-Desûkî ale'ş-Şerhi'l-kebîr. 4 Cilt. Beyrût: Dâru'l-fikr, ts.

Ebû Bekir er-Râzî, Muhammed b. Muhtâru's-sıhâh. thk. Yusuf eş-Şeyh Muhammed. Beyrut: elMektebetü'l-asriyye, 5. Basım, 1999.

Ebû Hafs Sirâcüddîn, Ömer b. Alî b. Ahmed el-Ensârî el-Mısrî. el-Bedrü'l-münîr fî tahrîci ehâdîsi'ş-Şerhi'l-kebîr. 9 Cilt. thk. Mustafa Ebu'l-Gayt-Abdullah b. Süleyman-Yasir b. Kemal. Riyad: Dâru'l-hicra, 2004.

Ebü'l-Fazl, Müslim b. Ali ed-Dımaşkî el-Mâlikî. el-Furûku'l-fıkhiyye. thk. Muhammed Ebü'lEcfân - Hamza Ebû Fâris. Libya: Dâru'l-hikme, 2007.

Erdoğan, Mehmet. Fıkıh ve Hukuk Terimleri Sözlüğü. İstanbul: Ensar, 4. Basım, 2013.

Gazzâlî, Hüccetü'l-İslâm Ebû Hâmid Muhammed b. Muhammed b. Muhammed b. Ahmed elGazzâlî et-Tûsî. el-Mustasfâ. thk. Muhammed Abdüsselam Abdü'ş-Şâfî. Beyrût: Dâru'lkutubi'l-ilmiyye, 1993.

Hattâb, Ebû Abdillâh Şemsüddîn Muhammed b. Muhammed b. Abdirrahmân el-Hattâb erRuaynî, Mevâhibü'l-celîl fî Şerhi Muhtasarı Halil. 6 Cilt. Beyrût: Dâru'l-fikr, 3. Basım, 1992.

İbn Ebû Şeybe, Ebû Bekir Abdullah b. Muhammed b. Ebî Şeybe İbrâhîm el-Absî el-Kûfî. Müsned. 2 Cilt. thk. Adil b. Yusuf el-Azazî-Ahmed b. Ferid el-Mezidî. Riyad: Dâru'l-vatan, 1997.

İbn Kudâme, Ebû Muhammed Muvaffakuddîn Abdullāh b. Ahmed b. Muhammed b. Kudâme elCemmâîlî el-Makdisî. el-Muğnî. 10 Cilt. Kahire: Mektebetü'l-Kahire, 1968.

İbn Manzûr, Ebü'l-Fazl Cemâlüddîn Muhammed b. Mükerrem b. Alî b. Ahmed el-Ensârî erRüveyfî̂. Lisânü'l-Arab. 15 Cilt. Beyrût: Dâru sâdır, 3. Basım, 1414/1994.

İbn Rüşd, Ebü'l-Velîd Muhammed b. Ahmed b. Ahmed el-Kurtubî el-Endelüsî. elMukaddimâtü'l-mümehhedât. 3 Cilt. thk. Muhammed Hacci. Beyrût: Dâru'l-garbi'lİslâmî, 1988.

İbn Rüşd, Ebü'l-Velîd Muhammed b. Ahmed b. Muhammed el-Kurtubî. Bidâyetü'l-müctehid. 4 Cilt. Kahire: Dâru'l-hadîs, 2004.

İbn Rüşd. el-Beyân ve't-tahsîl. 20 Cilt. thk. Muhammed Hacci vd.. Beyrût: Dâru'l-garbi'l-İslâmî, 2. Basım, 1988.

İbn Şebbe, Ebû Zeyd Ömer b. Şebbe en-Nümeyrî el-Basrî. Târîhu'l-Medîne. thk. Fehim Muhammed Şeltût. Cidde: 1399/1979. 
İbnü'l-Arabî, Ebû Bekir Muhammed b. Abdillâh b. Muhammed el-Meâfirî. Ahkâmu'l-Kur'ân. 4 Cilt. Beyrût: Dâru'l-kütübi'l-ilmiyye, 3. Basım, 2003.

İbnü'l-Arabî. el-Avâsım mine'l-kavâsım. thk. Ammâr Tâlibî. Mısır: Mektebetü dâri't-türâs, ts.

İbnü'l-Esîr, Ebü's-Seâdât Mecdüddîn el-Mübârek b. Esîrüddîn Muhammed b. Muhammed eşŞeybânî el-Cezerî İbnü'l-Esîr. Câmi'u'l-usûl fî ehâdîsi'r-Rasûl. 12 Cilt. thk. Abdülkadir el-Arnavut vd.. Dımaşk: Mektebetü'l-halvânî, 1972.

İbnü'l-Hümâm, Kemâlüddîn Muhammed b. Abdilvâhid b. Abdilhamîd es-Sivâsî el-İskenderî. Fethu'l-kadîr. 10 Cilt. Beyrût: Dâru'l-fikr, ts.

İbrahim, Mustafa vd.. el-Mu'cemu'l-vasît. İstanbul: Çağrı Yayınları, 1989.

Kâsânî, Alâüddîn Ebû Bekr b. Mes'ûd b. Ahmed el-Kâsânî. Bedâ’i' 'u's-sanẩi' fî tertîbi'ş-șerẩi' 7 Cilt. Beyrût: Dâru'l-kütübi'l-ilmiyye, 2. Basım, 1986.

Köksal, İsmail. "İslâm Hukuku'nda Zıhâr”. Dini Araştırmalar 3/7 (Mayıs-Ağustos 2000), 257269.

Kudûrî, Ebü'l-Hüseyn Ahmed b. Ebî Bekr Muhammed b. Ahmed el-Kudûrî. el-Muhtasar. thk. Kâmil Muhammed Uveyda. Beyrût: Dâru'l-kütübi'l-ilmiyye, 1997.

Kur'ân-ı Kerîm ve Açıklamalı Meâli. çev. Hayrettin Karaman vd.. Ankara: Türkiye Diyanet Vakfı Yayınları, 33. Basım, 2018.

Lehibî, Ahmet İbrahim Hızır. "Mâddetü z.h.r. el-mu'cemiyye ve delâlâtühâ fi'l-Kur'âni'l-Kerîm”. Mecelletü ebhâsi külliyyeti't-terbiyeti'l-İslâmiyye 2/4 (Ekim 2005), 181-207.

Mâverdî, Ebü'l-Hasen Alî b. Muhammed b. Habîb el-Basrî el-Mâverdî. el-Hâvi'l-kebîr. 19 Cilt. thk. Ali Muhammed Muavviz-Adil Ahmed Abdülmevcûd. Beyrût: Dâru'l-kütübi'lilmiyye, 1999.

Merî̂ b. Yûsuf, Zeynüddîn Merî̀ b. Yûsuf b. Ebî Bekr b. Ahmed b. Ebî Bekr el-Kermî. Gâyetü'lmüntehâ. 2 Cilt. Kuveyt: Müessesetü gırâs, 2007.

Meydânî, Abdülganî b. Tâlib b. Hammâde el-Meydânî el-Guneymî ed-Dımaşkî. el-Lübâb fî şerhi'l-Kitâb. 4 Cilt. thk. Muhammed Muhyiddin Abdülhamid. Beyrût: el-Mektebetü'lilmiyye, ts.

Molla Fenârî, Şemseddin Muhammed b. Hamza. Fusûlüll-bedâyi ' fî usûli'ş-şerâii 2 Cilt. thk. Muhammed Hüseyin Muhammed Hasan İsmail. Beyrût: Dâru'l-kütübi'l-ilmiyye, 2006.

Mübârekpûrî, Ebü'l-Ulâ Muhammed Abdurrahmân b. Abdirrahîm el-Mübârekpûrî. Tuhfetü'lahvezî. 10 Cilt. Beyrût: Dâru'l-kütübi'l-ilmiyye, ts.

Nesefî, Ebü'l-Berekât Hâfızüddîn Abdullah b. Ahmed b. Mahmûd en- Nesefî. Kenzü'd-dekâik. thk. Said Bektaş. Beyrût: Dâru'l-beşâiri'l-İ́slâmiyye, 2011.

Nesefî. Tefsîru'n-Nesefî. 3 Cilt. thk. Yusuf Ali Bedevî. Beyrût: Dâru'l-kelimi't-tayyib, 1998.

Nevevî, Ebû Zekeriyyâ Yahyâ b. Şeref b. Mürî en-Nevevî. el-Mecmû' şerhu'l-Mühezzeb. Beyrût: Dârul'l-fikr, ts.

Râzî, Ebû Abdillâh (Ebü'l-Fazl) Fahrüddîn Muhammed b. Ömer b. Hüseyn er-Râzî etTaberistânî. Mefâtîhu'l-ğayb. 32 Cilt. (Beyrût: Dâru ihyâi't-türâsi'l-arabî, 3. Basım,1420/1999.

Sa'dî, Ebû Habib. el-Kamûsü'l-fikhî lügaten ve's-tılâhân. Suriye: Dâru'l-fikr, 1993.

Semerkandî, Ebû Bekir Alâüddîn Muhammed b. Ahmed b. Ebî Ahmed es-Semerkandî. Tuhfetü'l-fukahâ. Beyrût: Dâru'l-kütübi'l-ilmiyye, 2. Basım, 1994.

Serahsî, Ebû Bekr Şemsü’l-eimme Muhammed b. Ebî Sehl Ahmed es-Serahsî. el-Mebsût. 30 Cilt. Beyrût: Dâru'l-marife, 1993.

Şâfiî, Ebû Abdillâh Muhammed b. İdrîs b. Abbâs eş-Şâfiî. el-Ümm. 8 Cilt. Beyrût: Dâru'l-marife, 1990. 
Şevkânî, Ebû Abdillâh Muhammed b. Alî b. Muhammed eș-Şevkânî es-San'ânî el-Yemenî. Neylü'l-evtâr. 8 Cilt. thk. İsamüddin es-Sabâbetî. Mısır: Dâru'l-hadîs, 1993.

Şirbînî, Şemsüddîn Muhammed b. Ahmed el-Hatîb eş-Şirbînî el-Kâhirî. Muğni'l-muhtâc ilâ ma'rifeti me ânî elfâzi'l-Minhâc. 6 Cilt. Beyrût: Dâru'l-kütübi'l-ilmiyye, 1994.

Taberî, Ebû Ca'fer Muhammed b. Cerîr b. Yezîd el-Âmülî et-Taberî el-Bağdâdî. Câmi'u'l-beyân fí te'vîli'l-Kur'ân. 24 Cilt. thk. Ahmed Muhammed Şâkir. Beyrût: Müessesetü'r-risâle, 2000.

Tâhir b. Âşûr. et-Tahrîr ve't-tenvîr. 30 Cilt. Tunus: ed-Dâru't-Tûnusiyye li'n-neşr, 1984.

Tahtâvî, Ali Ahmed Abdu'l-âl et-Tahtâvî. Tenbîhu'l-ebrâr bi'l-ahkâmi'l-hul'i ve't-talâki ve'zzıhâr. nşr. Muhammed Ali Beydûn. Beyrût: Dâru'l-kütübi'l-ilmiyye, 2003.

Tirmizî, Ebû Îsâ Muhammed b. Îsâ b. Sevre (Yezîd) et-Tirmizî. el-Câmi'u'l-kebîr. 6 Cilt. thk. Beşşâr Avvâd Marûf. Beyrût: Dâru'l-garbi'l-İslâmî, 1998.

Yaman, Ahmet. "Zıhâr". Türkiye Diyanet Vakfi İslâm Ansiklopedisi. 44/387-390. İstanbul: TDV Yayınları, 2013.

Yenişehirli, Şeyhülislam Ebu'l-Fazl Abdullah Efendi. Behcetü'l-fetâvâ. der. Mehmed Fikhi elAynî. İstanbul: Matbaa-i Âmire, 1266/1850.

Zebîdî, Ebü'l-Feyz Muhammed el-Murtazâ b. Muhammed b. Muhammed b. Abdirrezzâk elBilgrâmî el-Hüseynî ez-Zebîdî. Tâcü'l-arûs min cevâhiri'l-kâmûs. 40 Cilt. thk. Heyet. Kuveyt: Dâru'l-hidâye: ts.

Zemahşerî, Ebü'l-Kâsım Mahmûd b. Ömer b. Muhammed el-Hârizmî ez-Zemahşerî. el-Keşşâf 'an hakâ'ikı gavâmizi't-tenzîl ve 'uyûni'l-ekâvîl fí vücûhi't-te’vîl. 4 Cilt. Beyrût: Dâru'lkütübi'l-ilmiyye, 3. Basım, 1407/1987. 